\title{
Effect of Intercropping on Purple Blotch (Alternaria porri) of Onion (Allium cepa L.)
}

\author{
Dnyaneshwar R. Galande* and Sobita Simon
}

Department of Plant Protection Sam Higginbottom University of Agriculture, Technology \& Sciences, Allahabad-211007, India

*Corresponding author

\section{Keywords}

Purple blotch, Intercropping, Onion, Legumes, Yield

Article Info

Accepted:

10 January 2019

Available Online:

10 February 2019

\section{A B S T R A C T}

The field experiment was conducted at the Department of Plant Pathology SHUATS during the rabi season, to investigate the "Effect of intercropping on purple blotch (Alternaria porri) of onion (Allium cepa L.)" a legume intercrops evaluated were. Chickpea (Cicer arientinum), pea (Pisum sativum), lentil (Lens esculantum), french bean (Phaseolus vulgaris), cluster bean (Cyamopsis tetragonoloba), the efficacy of the legume intercrops in reducing the foliar disease was compared to a fungicide carbendazim $(0.1 \%)$. each legume crop was intercropped with onion variety (Nashik red N-53) purple blotch development were determined until physiological maturity. Legume and bulb yields were also determined at harvest. French bean was the most effective legume intercrop in reducing purple blotch incidence by up to $49.1 \%$ and chickpea was most effective legume intercrop in increasing plant height $(46.83)$, weight $(35.53 \mathrm{gm})$ and size $(5.20 \mathrm{~cm})$ of onion bulb. Although intercropping onion with legume reduced bulb yield, it improved the gross return per unit area. The disease occurrence in intercrops was also recorded as a result Powdery mildew and Alternaria blight diseases were occurred in pea, Alternaria leaf spot in french bean, and disease vascular wilt in both lentil and chickpea crops was recorded. The results showed that intercropping onion with legume could be beneficial in reducing foliar disease and improving gross return per unit area. However, further studies are necessary to determine the optimal spatial arrangement of onion and legume intercrops in foliar disease management.

\section{Introduction}

The onion (Allium cepa L.) (Latin 'cepa' = onion), also known as the bulb onion or common onion and is rightly called as "Queen of Kitchen" and is one of the oldest known and important vegetable crops grown in India. According to Vavilov 1951 the primary center of origin lies in Central Asia. Onion (Allium cepa L.) is the most important bulb crop grown for human consumption world wide and it is among the most important horticultural crop (FAO STAT, 2004). The onion is native to south west Asia or Mediterranean, considered important commercial vegetable crop in the world (Wani and Taskeen, 2011). 
Intercropping field vegetable with other crop species is increasing gaining popularity as a potential alternative to the use of chemicals (Trdan et al., 2005, 2006). Intercropping is commonly use of vegetable crop fits into environmentally acceptable and sustainable crop production practices widely adopted by small holding farmer. This concept entails growing two or more economic species together for at least a portion of their respective productive life cycle, planting them sufficiently close to each to allow for inter specific competition (kabura et al., 2008). Benefits of intercropping include optimal use of resources, stabilization of yield, weed suppression, improved soil fertility conservation and higher economic returns (Trdan et al., 2011).

Purple blotch of onion caused by Alternaria porri is an important disease of onion worldwide except in very cool production area (Awad et al., 1978; Evert and Lacy, 1990a; Brar et al., 1990; Aveling et al., 1993, 1994; Chaput, 1995, Cramer, 2000; Schwartz et al., 2005). It is especially troublesome in warm and humid environments (Suheri and price, 2000).The fungus attacks both leaves and flower stalks (Bock, 1964), reducing foliar production by $62-92 \%$ (Suheri and Price, 2001). The disease can cause a yield loss of 30\% (Everts and Lacy, 1990b) and $100 \%$ of the seed crop when the weather favours it (Daljeet et al., 1992; Schwartz., 2004). Purple blotch disease of onion is important as a disease complex that nutrition (Awad et al., 1978), cultural practices (Arboleya et al., 2003), environmental conditions (Everts and Lacy, 1990a; Suheri and Price, 2000, 2001) and prevalence of other disease factors (Brar et al., 1990) all contribute to resistance or susceptibility to the disease, thereby making it more difficult to control. The most reliable measure of control of the disease so far is through crop rotation and use resistance varieties (Delahaut and
Stevenson, 2004; Latin and Helrns, 2001) or good cultural practices (Schwartz, 2004; Allen, 2005). Intercropping bulb onion with vegetables could be beneficial in reducing foliar disease and improving gross return per unit area (Narla, 2011).

\section{Materials and Methods}

\section{Experimental site and treatment}

The field experiment on purple blotch disease of onion was carried out in research field of Sam Higginbottom University of Agriculture, Technology \& Sciences, Allahabad during 2017-2018. In the present study experiment was lay out in randomized block design with 7 treatments and 3 replications. The Nashik Red N-53 variety of onion was sown in different legume intercrops (chickpea, pea, lentil, cluster bean, French bean).The size of main plot is $2.5 \times 2 \mathrm{~m}$, Sowing ratio (intercrop + Onion + intercrop 1:2:1), Sowing of onion seed (nursery preparation) in date $15^{\text {th }}$ Oct 2017. The onion seed were collected from Alopybagh, Allahabad. The onion seedlings were transplanted in the main plots at spacing of $25 \times 20 \mathrm{~cm}$. The intra-row spacing was 20 $\mathrm{cm}$ for french bean, cluster bean, pea and chickpea for lentil it was $15 \mathrm{~cm}$. The control plots consist of onion with and without fungicide (Carbendazim 0.1\%) applied at the rate of $0.1 \mathrm{gm} /$ lit. The legume intercrops were sown before transplanting the onion. The fertilizer were applied at the rate of $40 \mathrm{~kg}$ $\mathrm{N} /$ ha in intercrops only.

\section{Symptoms of pathogen}

The purple blotch symptoms on onion initially appears on leaves or inflorescence as small (2-3 $\mathrm{mm}$ in dia) water soaked lesions that quickly develop white centre under favourable conditions vary from small, elliptic white lesions to large, sunken purple lesions with concentric dark and light zones 
Later these lesions enlarge, coalesce and turn brown to purple extending upwards and downwards (Verma and Sharma, 1999).

\section{Methods of recording observation}

Observation on disease incidence \% was recorded at 60, 75 and 90 days after Sowing. Disease incidence was determined according to Abubakar (2013).

Disease incidence $(\%)=$

Total number of infected plants

Total number of plants

\section{Cost benefit ratio}

The benefit cost ratio was calculated using the following formula (Reddy and Reddi, 2004).

\section{Cost Benefit Ratio = \\ Gross Return (Rs/ha)}

Total cost of cultivation X100

\section{Analysis of variance}

The data recorded during the course of investigation was statistically analyzed among genotypes by F-test. It was carried out according to the procedure of Randomized Complete Block Design procedure for each character as per methodology advocated by Panse and Sukhatme, (1967).

\section{Results and Discussion}

\section{The effect of intercropping on purple blotch}

Result of 90 days after transplanting (DAT) indicates that significantly reduced the purple blotch disease was recorded in treatment of carbendazim (21.84\%), as compared with intercropping treatment. Onion + french bean 2:1 $(49.01 \%)$ and Onion + pea 2:1 (49.15\%), is the best treatment for controlling the purple blotch disease (Table 1). Comparing the result with C.D. value it was found that $T_{6}$ (carbendazim) was significantly superior overall treatments and among the intercrops onion + French bean was effective.

Effect of intercropping on plant height, weight, size and onion bulb yield

The maximum plant height, weight, size and yield were recorded in treatment, onion + chickpea. It was best treatment as compare to sole onion (Table 2). The reduction in bulb yield due to intercropping of onion with other legume was compensated by the additional yield from the legume crop resulting in higher gross return per hectare (Table 3 ).

\section{Disease occurs in other crop plants}

The disease occurrence in intercrops was also recorded as a result Powdery mildew and Alternaria blight disease were occurred in pea, Alternaria leaf spot in french bean, and disease Vascular wilt in both lentil and chickpea crops was recorded.

This study has demonstrated that legume intercrops were effective in reducing purple blotch on onion. The result of the study agree with reports by Sahile et al.,(2008), Who demonstrated the suppression of chocolate spot (Botrytis fabae) on faba bean when intercropped with field pea, barley or maize. Narla et al., (2011) demonstrated the effectiveness of vegetable intercrops in the management of downy mildew and purple blotch disease. Vegetable intercropped with carrot spider plant French bean. The effect of barley-legume intercrop in an organic farming system on disease incidence was investigated. 
Table.1 Effect of Intercropping on percent of disease incidence of purple blotch (Alternaria porri) on onion at different time intervals

\begin{tabular}{|l|l|l|l|}
\hline Treatment & $(60$ DAT $)$ & $(\mathbf{7 5}$ DAT $)$ & $(90$ DAT $)$ \\
\hline sole onion & 39.45 & 47.19 & 54.20 \\
\hline onion + chickpea & 38.50 & 46.96 & 53.04 \\
\hline onion + pea & 36.17 & 43.99 & 49.15 \\
\hline onion + lentil & 37.34 & 45.03 & 53.22 \\
\hline onion + cluster bean & 36.21 & 44.09 & 52.46 \\
\hline $\begin{array}{l}\text { onion+ french bean } \\
\text { Onion + }\end{array}$ Carbendazim & 13.48 & 17.13 & 21.84 \\
\hline CD at $(0.5 \%)$ & $\mathbf{2 . 2 6 0}$ & $\mathbf{1 . 5 1 6}$ & $\mathbf{1 . 5 8 6}$ \\
\hline
\end{tabular}

DAT: days after transplanting, CD: critical difference

Table.2 Effect of intercrops on plant height $(\mathrm{cm})$, weight $(\mathrm{gm})$ and size of onion bulb at different time intervals

\begin{tabular}{|l|l|l|l|l|l|}
\hline Treatment & $\begin{array}{c}\mathbf{6 0} \\
\text { (DAT) }\end{array}$ & $\begin{array}{c}\mathbf{7 5} \\
\text { (DAT) }\end{array}$ & $\begin{array}{l}\mathbf{9 0} \\
\text { (DAT) }\end{array}$ & $\begin{array}{l}\text { Wt. of } \\
\text { bulb }\end{array}$ & $\begin{array}{l}\text { Size of } \\
\text { bulb }\end{array}$ \\
\hline sole onion & 24.70 & 31.67 & 36.17 & 25.94 & 2.84 \\
\hline onion + chickpea & 32.27 & 39.00 & 46.83 & 35.35 & 5.20 \\
\hline onion + pea & 27.13 & 34.13 & 40.27 & 30.45 & 3.94 \\
\hline $\begin{array}{l}\text { onion + lentil } \\
\text { onion + cluster }\end{array}$ & 30.00 & 37.07 & 44.13 & 33.70 & 4.45 \\
\hline bean & 29.03 & 35.27 & 43.20 & 31.59 & 3.91 \\
\hline onion+ french bean & 26.47 & 34.07 & 39.07 & 29.35 & 3.87 \\
\hline \begin{tabular}{l} 
Onion + fungicide \\
\hline CD at $(0.5 \%)$
\end{tabular} & 25.53 & 33.00 & 37.00 & 26.70 & 2.93 \\
\hline 2.14 & $\mathbf{1 . 1 4}$ & $\mathbf{1 . 6 4}$ & $\mathbf{1 . 2 1}$ & $\mathbf{0 . 7 0}$ \\
\hline
\end{tabular}

DAT: days after transplanting, WT: weight, CD: critical difference

Table.3 Average return per hectare of bulb onion in sole onion or intercropped with other legumes

\begin{tabular}{|l|l|l|l|}
\hline Treatment & $\begin{array}{l}\text { Intercrops } \\
\text { Kg / ha }\end{array}$ & $\begin{array}{l}\text { Bulb } \\
\text { onion } \\
\text { Kg/ ha }\end{array}$ & $\begin{array}{l}\text { Gross } \\
\text { income }\end{array}$ \\
\hline sole onion & 0.00 & 3400 & 51000 \\
\hline onion + chickpea & 1768 & 2520 & 99680 \\
\hline onion + pea & 1120 & 2260 & 61900 \\
\hline onion + lentil & 1090 & 2380 & 84750 \\
\hline onion + cluster bean & 1136 & 2280 & 68280 \\
\hline onion+ french bean & 1380 & 2200 & 74000 \\
\hline Onion + Carbendazim & 0.00 & 4000 & 63600 \\
\hline
\end{tabular}

The legumes were lupin, faba bean and pea. pea, only ascochyta blight (Ascochyta pisi) Diseases were detected on pea and barley. On was observed. When either pea variety was 
intercropped with barley, the level of ascochyta blight was reduced. Net blotch (Pyrenophora teres), brown rust (Puccinia recondita) and powdery mildew (Blumeria graminis f. sp. hordei) (in order of incidence) were monitored on barley between flag leaf emergence and heading. The levels of all three diseases were reduced in every intercrop treatment compared to the barley monocrop. However, this reduction was only statistically significant in the pea treatments for neck blotch Kinane et al., (2002).

Intercropping onion with the vegetable reduced both total and marketable bulb yield. This is the agreement with finding by Trden et al., (2006). The reduction in yield due to intercropping of onion with other vegetables was compensated by the additional yield from the vegetable resulting in higher gross return per hector Trdan et al., (2011). The reduction in yield could have been caused by the reduction in onion population and intercrop competition for nutrients, water and light Ansari and Mamgham (2008). The reduction in bulb bulb yield may be compensated by the yield from the vegetable intercrops and, therefore no net loss to the farmer. In addition, the intercrop may act as buffer against total crop loss and diversifies the production. therefore, the Onion-vegetable intercrops would be suitable to small scale farmers who do not have adequate resources for purchase of chemical fungicides. The system would also be very ideal for organic vegetable production in which chemical application is not desirable. Apart from increasing total farm productivity, mixed species cropping can bring many important benefits such as improvement of soil fertility management and suppression of pest and disease Ramert and Lennartsson (2002). Demonstrated the Pea intercropped with garlic, turnip, cauliflower. Observe the maximum yield loss of garlic in the peagarlic intercrop system Anjum et al., (2014).
From present study, it was concluded that intercropping of onion with french bean were found as best treatment to minimize purple blotch disease in small holder onion production systems, were as for maximum yield, bulb weight and size of bulb intercropping of onion with chickpea was found to be most effective. Since chemicals have many hazardous effects on the environment as well as on the person who handles it while application in the field and consumers using the product, so used of intercropping system in field condition would be considered as better, as it is beneficial and eco-friendly. Since, one year data is not sufficient to conclude concurrent result, further experimentations are required to confirm the results.

\section{References}

Awad, M. A., Sheawy, Z. E. L., Omran, A. F. and Shatla, M. N. (1978). Cultural practices in relation to purple blotch disese of onion. Sci. Hortic, 9:237-243.

Abubakar, L. and Ado, S. G. (2013). Genotype - environmental interaction for resistance to purple blotch (Alternria porri L.(Ellis) Cif.) in onion (Allium cepa L.) in Nigeria, Asian journal of crop science, 1(1):15-25.

Aveling, T. S, and Naude, S. P. (1992). First report of Alternaria porri on Onion and Garlic in South Africa. Plant Disease, 76-643.

Anjum, M. A., Syed, A. Q., Shakeel, A. And Sajjad, H. (2014). Assessment of advantages of pea and non-legume winter vegetable intercropping systems through competition and economic indices. Expl Agric. 1(17)10.1017.

Arboleya, J., Zandstra, B., Rocha, A. A., Widders, I. and Hammerschmidt, R. (2003). Induced disease resistance and raised beds reduce purple blotch disease of onion. HortScience, 38(5):763. 
Allen, J., (2005). Purple blotch of onions. Canada ministry of Agriculture, food and rural affairs, Ontario. http://www.omafra. gov.on.ca/english/hort/news /horttmatt.

Ansari, N. A. and R. Mamghani, (2008). Effect of screening of onion (Allium cepa) ecotypes of southern Iran on bulb yield and bolting. Asian journal of plant science. 7:584-588.

Bock, K. R. (1964). Purple blotch (Alternaria porri) in Kenya. Ann. Applied Biol., 54: 303-311.

Brar, S. S., Rewal, H. S. and Singh, H. (1990). Development of purple blotch of onion in relation to thrip injury. Plant Dis. Res., 5:133-135.

Chaput, J. (1995). Identification of disese and disorders of onion. FACT SHEET. Queens Printers for Ontario. Ontario, Canada, pp:1-9.

Cramer, C. S. (2000). Breeding and genetics of fusarium basal rot resistance in onion. Euphytica, 115:159-166.

Daljeet, S., Dhiman, J. S., Shidhu, A. S. and Singh, H. (1992). Current status of onion in India: Strategies for disease resistance breeding for sustained production. Newslett. Trop., 4:43-44.

Delahaut, K. and Stevenson, W. (2004). Onion disorders: Purple blotch. University of Wisconsin Extension Manual, pp:1-2.

Everts, K.L. and Lacy, M. L. (1990). Influence of environment on conidial concentration of Alternaria porri in air and on purple blotch incidence on onion. Phytopathology, 80(12):13871391.

FAOSTAT (2004). FAOSTAT Database Results. http://www.faostat.org.

Kabura, B.H., B. Musa and P.E, Odo, (2008). Evalution of the components and yield of onion (Alium cepa L.) pepper (Capsicum annum L.) intercrop in the Sudan savanna. Journal of
Agronomy.,7:88-92.

Kinane, J. and Lyngkjaer, M. F. (2002). Effect of barley - legume intercrop on disease frequency in an organic farming system. Risoe National Laboratory, Resistance Biology Programme, DK 4000 Roskilde, Denmark.

Latin, R. and K. Helms, (2001). diagnosis and control of onion disease. purdue university cooperative extension service, west Lafayette, Indiana. http://www.ces.

Purdue.edu/extmedia/BP/BP-23W.html.

Narla, R. D., Muthomi, J. W., Gachu, S. M., Nderitu, J. H. and Olubayo, F. M. (2011). Effect of intercropping bulb onion and vegetables on purple blotch and downy mildew. Journal of Biological Sciences, 11:52-57.

Panse, V. G. and Sukhatme, P. V. (1967). Statistical Methods for Agricultural Workers, Indian Council of Agricultural Research, New Delhi, p. 381.

Ramert, B. M. and Lennartsson, D. G. (2002). The use of mixed species cropping to manage pests and diseases-theory and practice. Proceedings of the COR Conference, March 26-28, Aberystwyth, Pp: 207-210.

Schwartz, H. F. (2004). Botrytis, downy mildew and purple blotch of onion. Colorado State University Cooperative $\begin{array}{lll}\text { extension } & \text { No. } & 2 .\end{array}$ http://www.ext.colostate.edu.

Schwartz, H. F., Gent, D. H. and Brartolo, M. E. (2005). Purple blotch. http://wwwhighplainsipm.org. HplPMSearch/ Docs/purple blotchonion.htm.

Sahile, S., C. Fininsa, P. K. Sakhuja and S. Ahamad, (2008). Effect of mixed cropping and fungicides on chocolate spot Botrytis faba bean (Vicia faba) in Ethiopia. J. Crop protect., 27:275-282.

Suheri, H. and T.V. Price, (2000). Infection of 
onion leaves by Alternaria porri and Stemphylium vesicarium and disease development in controlled environments. Plant Pathol., 49:375382.

Suheri, H. and Price, T. V. (2001). The epidemiology of purple blotch on leeks in victoria, Australia. Eur.J.Plant Pathol., 107:503-510.

Trdan, S., Milevoj, L., ZeZlina, I., Raspudic, E. and Andjus, L. (2005). Feeding damage by onion thrips, Thrips tabaci Lindeman (Thysanoptera: Thripidae), on early white cabbage grown under insecticide-free conditions. Afr. Entomol.,13:85-95.

Trdan, S., Znidar, D., Vali, N., Rozman, L. and Vidrih, M. (2006). Intercropping against onion thrips, Thrips tabaci
Lindeman (Thysanoptera: Thripidae) in onion production: On the suitability of orchard grass, lacy phacelia and buckwheat as alternatives for white clover. Journal of Plant Disease Protection, 113:24-30.

Tardan, S. and Jhooty, J. S. (2011). Association of thrips with purple blotch infection on onion plants caused by Alternaria porri. Indian Phytopathol. 35: 696-698.

Verma, L.R. and Sharma, R.C. (1999). Diseases of horticultural crops vegetables, ornamentals and mushrooms. Indus Publishing Company, New Delhi, p 353356.

Wani, A.H and taskeen-Un-Nisa (2011). Management of black mould rot of onion mycopath. 9(1): 43-49.

\section{How to cite this article:}

Dnyaneshwar R. Galande and Sobita Simon. 2019. Effect of Intercropping on Purple Blotch (Alternaria porri) of Onion (Allium cepa L.). Int.J.Curr.Microbiol.App.Sci. 8(02): 1105-1111. doi: https://doi.org/10.20546/ijcmas.2019.802.129 